\title{
Responsibility for employees as a challenge for contemporary organizations
}

\section{Magdalena WRÓBEL}

\section{WSB University of Dąbrowa Górnicza, Poland}

\begin{abstract}
:
Aim: The paper considers the issue of responsibility on the part of contemporary organizations for their employees. In her paper, the author described ISO 26000 guidelines for organizations concerning labor practices and the impact of these guidelines on competitiveness of organizations. The paper also analyzed labor practices implemented by firms in Poland in the years 2013-2015.
\end{abstract}

Design / Research methods: Based on statistical data and literature study as well as Responsible Business in Poland. Good practices reports., the period 2013-2015 is considered for analysis.

Conclusions / findings: Entrepreneurs in Poland seem to take more responsibility for employees, while recognizing the key role played by human capital in building competitive advantage of an organization. This also supports the company's image and competitiveness, while improving employee loyalty.

Keywords: human capital, contemporary organizations, responsibility for employees, corporate social responsibility, ISO 26000 standard, Poland.

JEL: M5, M14

\section{Introduction}

Responding to stakeholders' expectations, it is ever more common and on a wider scale that today's firms implement diversified measures of corporate social responsibility. Those measures also address employees, who are classified as primary stakeholders (Bartkowiak 2011: 32-33). It should, however, be emphasized that meeting the expectations of stakeholder groups is not proportional.

Contact details: Magdalena WRÓBEL, WSB University of Dąbrowa Górnicza, Poland, E-mail: madziawrobel@gmail.com

Received: 01.01.2017, Revised: 12.04.2017, Revised: 13.04.2018, Accepted: 13.04.2018

doi: http://dx.doi.org/10.29015/cerem.401 
Entrepreneurs focus mainly on customers as this is what leads to increased satisfaction and positive reviews of the firm (Luo, Bhattacharya 2006). Considering the strategic role played by employees, corporate social responsibility should, in the first place, be concerned with satisfying the needs and expectations of this group of stakeholders. The level of employees' effectiveness, their work commitment and the extent to which they identify with organization, as well as their loyalty are largely dependent on how they are treated, in other words, how human capital is being managed in organization. Moreover, the responsibility for employees has a positive impact on the organization's efficient functioning and on its performance. The aim of the paper is to discuss the importance of human capital for contemporary organizations, to present the responsibility for employees in the light of the provisions of ISO 26000 standard and to conduct an analysis of labor practices of firms in Poland over the period of 2013-2015.

\section{The importance of human capital for contemporary organizations}

One can come across a number of definitions of human capital in the literature. Human capital refers to all specific characteristics and properties embodied by members of an organization (including knowledge, skills, abilities, health, motivation, etc.) which have a specific value representing the source of future income for both the employee - the owner of human capital, and the organization using this capital (Król, Ludwiczyński 2006: 96-98). L. Edvinsson and M.S. Malone define human capital as "combined knowledge, skill, innovativeness and ability of the company's individual employees to meet the task at hand." (Edvinsson, Malone 2001: 17). Moreover, J. Samul notes that while defining human capital the elements which are mentioned most frequently are those which make up human capital. In definitions of the structures of human capital, the aspect to appear most often is that of education, competence, attitudes and personal characteristics (Samul 2013: 201).

Numerous authors stress the key role of human capital for today's organizations. According to E. Skrzypek, people represent a substantial strategic resource of every firm. This resource is the source for value creation and competitive advantage; in 
other words, business success should be mainly associated with human capital (Skrzypek 2009: 208-209). J. Dzieńdziora and M. Smolarek emphasize that what is crucial nowadays for shaping the firm's competitiveness is the development of human potential which is taken into consideration while drawing up and implementing the firm's strategy (Dzieńdziora, Smolarek 2010: 82). M. Juchnowicz suggests that human capital is becoming the primary creator of value, as well as the factor determining the firm's competitive position (Juchnowicz 2007: 15). In a contemporary enterprise, people should be seen as the most valuable assets while their constant development ought to be ensured by the organization. While other assets tend to be depreciated over time, human assets are capable of multiplying rapidly their value through the process of learning (Rosińska 2007: 11-20). People, both as individuals or teams, are the basic elements of organizations - people constitute their content and form. For an organization, "to be or not to be" question lies in the hands of its members because it is the people who create, change and even annihilate their organizations (Godlewska 2008: 71). The characteristics which make human capital stand out compared to other types of capital in organization, is its qualitative character developed slowly by the individual himself or herself and by the organization, with this character being difficult to record and measure. It cannot be used as an object of trade, it has to be unique, difficult to copy by competition, and, above all, it cannot be passed to another owner (Pocztowski 2007: 41). It is therefore critical for the organization to understand the essence and importance of staff selection at the very beginning of its operations, and to remember that management is a continuous process involving constant development and improvement (Dzieńdziora, Smolarek 2010: 82).

However, the managerial staff in an organization has to be aware that in today's organizations people are employed in various capacities, under different working time and on the basis of diversified types of contracts. This is why the firm's activity in this respect should be focused on responsible treatment of all the categories of employees working in contemporary organizations, with a possible classification of those categories being as follows:

- regular employees - full-time workers employed permanently in a firm; the organization bears all the costs related to those employees; 
- partnership talent - employees being part of a partnership or joint ventures who are taken into account in related balance sheet;

- borrowed talent - employees who are part of the value chain or ecosystem who, however, are not considered in the firm's balance sheet, e.g. contractors sent by external firms to perform supportive roles;

- independent talent - freelancers hired for specific projects or on a temporary basis;

- open source talent - individuals who perform services for firms free of charge, acting independently or in a community - e.g. people who answer questions about the firm's products on its Internet sites under open source help functions (Deloitte 2013).

\section{Responsibility for employees in the light of provisions of PN-ISO 26000: 2012 standard}

The organization's responsibility for employees has been comprehensively addressed in ISO 26000 standard, which is an international standard comprising guidelines on social responsibility, that is, the responsibility of an organization for the impact, exerted by its decisions and actions, on society and the environment with this responsibility being ensured by transparent and ethical behavior which:

- fosters sustainable development, including that of society's health and welfare;

- takes into account stakeholders' expectations (individuals or groups who take interest in the organization's decisions or actions);

- is compliant with applicable law and consistent with the international standards of behavior;

- is incorporated into the organization's operations and is practiced in its relationships referring to the organization's actions taken within its sphere of influence. ISO 26000 standard provides no requirements and as such it is not to be certified, being intended for use on a voluntary basis by all 
organizations, whatever their ownership form, size, type and location (PKN 2010: 2).

The following seven core subjects of social responsibility have been distinguished in ISO 26000 standard:

- organizational governance,

- human rights,

- labor practices,

- the environment,

- fair operating practices,

- consumer issues,

- local community involvement and development (ISO 26000).

The guidelines addressing organizations and referring to labor practices included in ISO 26000 have been formulated according to five subjects: employment and employment relationships, conditions of work and social protection, social dialogue, occupational health and safety, human development and training in the workplace. Selected guidelines for organizations are presented in Table 1 .

The guidelines for organizations on employment and employment relationships pertain predominantly to respecting the provisions of labor law, to having no discrimination at workplace, as well as to treating employees and subcontractors ethically. The guidelines formulated in the field of Conditions of work and social protection focus on organizations to ensure working conditions that are compliant with law regulations, decent wages, working hours and rest, as well as equal payment for the same work and paying workers for overtime. With respect to the Social dialogue issue, the guidelines provided for in ISO 26000 refer first and foremost to respecting workers' right to establish organizations or to join already existing labor organizations, and to the organization's cooperation with social dialogue institutions. Another issue that ISO 26000 standard does not neglect are the guidelines on occupational health and safety. Recommendations within this area comprise such issues as the OSH risk analysis and control, devising and implementing OSH policy, providing the required safety equipment, ensuring that all employees receive OSH training - regardless of the form and working hours of their employment. What is important, the guidelines laid down in ISO 26000 also 
include those referring to employees' development which propose that the organization creates opportunities for development and promotion without discrimination, and if necessary, to ensure support for discharged workers in finding a new job, as well as creates social programs promoting health and welfare.

Table 1. Guidelines for organizations on labor practices

\begin{tabular}{|c|c|}
\hline $\begin{array}{c}\text { Labor } \\
\text { practices issues }\end{array}$ & Guidelines for organizations \\
\hline $\begin{array}{l}\text { Issue } 1 \\
\text { Employment } \\
\text { and } \\
\text { employment } \\
\text { relationships }\end{array}$ & $\begin{array}{l}\text { The organization is recommended: } \\
\text { not to eschew the obligations which the law requires from employer, } \\
\text { to ensure equal opportunities for all workers, allowing for no } \\
\text { discrimination, } \\
\text { to eliminate any arbitrary or discriminatory practices of discharging } \\
\text { workers, to protect personal data and privacy of employees, } \\
\text { not to benefit from unfair, exploitation or abuse-based labor practices } \\
\text { used by the organization's partners, suppliers or subcontractors, } \\
\text { including those providing remote work. }\end{array}$ \\
\hline $\begin{array}{c}\text { Issue } 2 \\
\text { Conditions of } \\
\text { work and } \\
\text { social } \\
\text { protection }\end{array}$ & $\begin{array}{l}\text { The organization is recommended: } \\
\text { to ensure that working conditions are compliant with national law and } \\
\text { are consistent with applicable international labor standards, } \\
\text { to ensure decent conditions of work with respect to wages, working } \\
\text { hours, weekly rest, holidays, health and safety issues, maternity } \\
\text { protection and the possibility of combining work with family duties, } \\
\text { to enable employees to follow their national or religious customs and } \\
\text { tradition } \\
\text { to ensure equal payment for work of the same value, } \\
\text { to respect the employees' right to work normal or agreed on hours, laid } \\
\text { down by the law, regulations or collective agreements, } \\
\text { to pay for overtime in accordance with the law, regulations or collective } \\
\text { agreements. }\end{array}$ \\
\hline $\begin{array}{l}\text { Issue } 3 \text { Social } \\
\text { dialogue }\end{array}$ & $\begin{array}{l}\text { The organization is recommended: } \\
\text { to recognize the importance of social dialogue institution for the } \\
\text { organization, including that at an international level, } \\
\text { to always respect workers' right to establish their own labor } \\
\text { organizations or to join them with a view to promoting their own } \\
\text { interests or collective arrangements, } \\
\text { not to impede workers from founding their own labor organizations or } \\
\text { joining them, } \\
\text { not to prompt governments to constrain the rights to freedom of } \\
\text { association recognized on an international scale, }\end{array}$ \\
\hline
\end{tabular}


Table 1. Cont. ...

\begin{tabular}{|c|l|}
\hline $\begin{array}{c}\text { Labor } \\
\text { practices issues }\end{array}$ & Guidelines for organizations \\
\hline \multirow{2}{\text{Issue4}}{$\begin{array}{l}\text { The organization is recommended: } \\
\text { to draw up, implement and maintain health and safety policy based on } \\
\text { the principle that strict health and safety standards and the organization } \\
\text { functioning are mutually supportive and strengthening areas, } \\
\text { to analyze and control OHS risk present in the organization's } \\
\text { operations, } \\
\text { to notify and } \\
\text { practices and to ensure that employees act in accordance with the } \\
\text { relevant procedures, } \\
\text { to provide safety equipment necessary, including personal protective } \\
\text { equipment, } \\
\text { to ensure the same OSH protection for employees working part-time } \\
\text { and on a temporary basis, as well as subcontractors, } \\
\text { to seek to eliminate psychosocial risks in the workplace which } \\
\text { contribute or lead to stress and illnesses, } \\
\text { to provide the entire staff with adequate training in terms of all } \\
\text { important issues. }\end{array}$} \\
$\begin{array}{l}\text { The organization is recommended: } \\
\text { to ensure that all workers have access, at every stage of their career, to } \\
\text { the development of skills, to training and practice, and have the } \\
\text { opportunity to be promoted in conditions free of discrimination, } \\
\text { if necessary, to provide workers who have been discharged with } \\
\text { assistance in looking for support, new job, training and career guidance } \\
\text { and counseling services, } \\
\text { to create joint programs promoting health and welfare with the } \\
\text { participation of representatives of workforce and management staff }\end{array}$ \\
$\begin{array}{c}\text { development } \\
\text { and training int } \\
\text { the workplace }\end{array}$ \\
\hline
\end{tabular}

Source: self-reported data based on PKN (2012: 46-53).

The ISO 26000 guidance on work addresses in a comprehensive way the employment issues and the organization's responsibility for its workers. As such, the responsibility for workers is to incorporate the ISO 26000 guidelines on labor practices into the organization's management process.

Human capital bears substantially on the organization's competitive advantage (see Figure 1). This is why one should emphasize the positive impact of the ISO 26000 provisions on the development of human capital in the organization, and thereby on its competitive position. As already mentioned, incorporating the ISO 26000 guidelines into the organization's management process demonstrates a holistic responsibility for employees. Employees who are treated by their employer 
in a responsible way are loyal, committed to work and take actions fostering their development. The organization thus gains competitive advantage through an important factor, which is high-value human capital.

Figure 1. ISO 26000 guidance and business competitive advantage

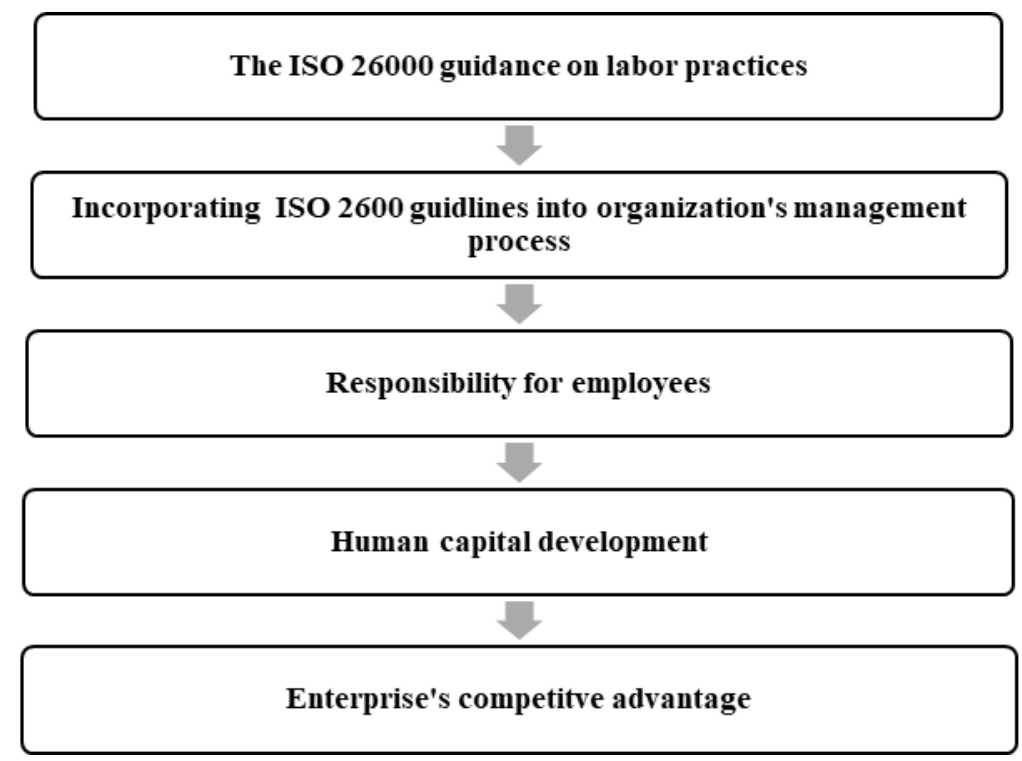

Source: self-reported data.

4. Analysis of labor practices of businesses in Poland over the period of 20132015

The analysis of Responsible business in Poland. Good practices reports from the years 2013-2015 (FOB 2013, 2014, 2015) allowed for gaining insight into the scale of labor practices implemented by businesses in Poland. It is worth noting that the report Responsible business in Poland. Good practices is the most important publication of the Responsible Business Forum in which its authors seek to demonstrate in a comprehensive way significant events and activities within corporate social responsibility in Poland over the past year, as well as companies' good practices. The presentation of good practices unfolds according to their 
breakdown into the seven core subjects of corporate social responsibility as distinguished in ISO 26000.

Throughout the years 2013-2015, the number of labor practices implemented by businesses in Poland nearly doubled - it grew from 67 in 2013 to 113 practices in 2015 (see Figure 2).

Figure 2. Labor practices implemented by businesses in Poland over the period of 2013-2015

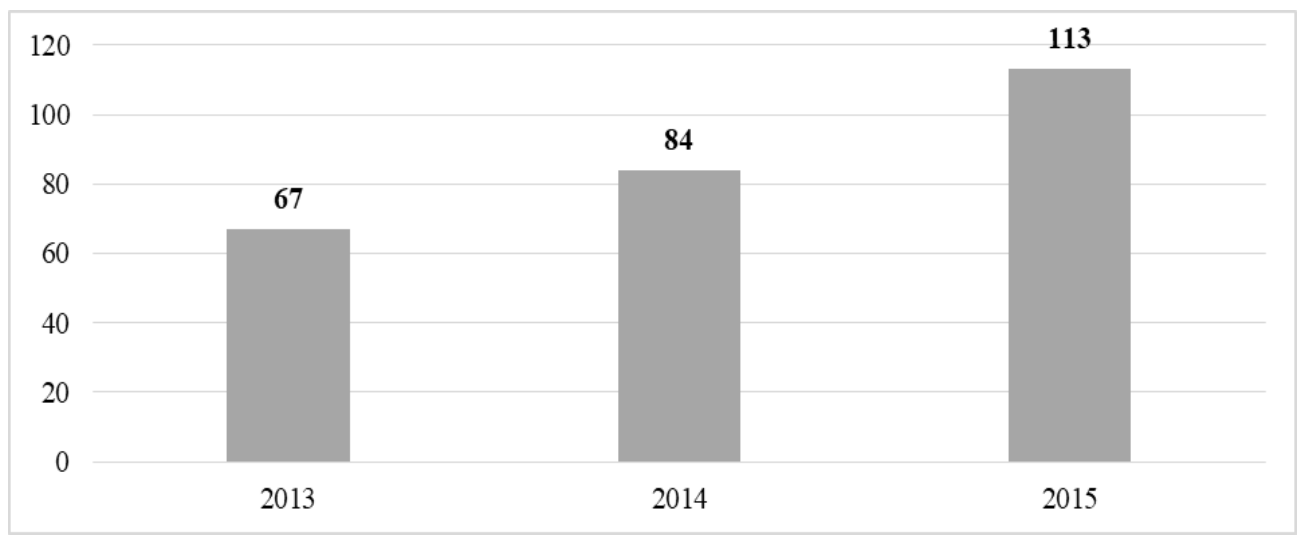

Source: self-reported data based on FOB $(2013,2014,2015)$.

Table 2. The areas of labor practices implemented by businesses in Poland in 2013

\begin{tabular}{|l|c|}
\hline Area of labor practice & Frequency of observed labor practices \\
\hline Employer-supported employee volunteering & 15 \\
\hline Employees' health & 13 \\
\hline Training and development & 9 \\
\hline Safety in the workplace & 7 \\
\hline Dialogue with employees & 5 \\
\hline Recruitment and adaptation & 5 \\
\hline Parent-friendly company & 4 \\
\hline Integration of employees & 3 \\
\hline Worker participation & 3 \\
\hline Work-life balance & 2 \\
\hline Support for employees & 1 \\
\hline $\begin{array}{l}\text { Countering workplace bullying and } \\
\text { harassment }\end{array}$ & 0 \\
\hline
\end{tabular}

Source: self-reported data based on FOB (2013). 
Table 3. The areas of labor practices implemented by businesses in Poland in 2014

\begin{tabular}{|l|c|}
\hline Area of labor practice & Frequency of observed labor practices \\
\hline Safety in the workplace & 14 \\
\hline Training and development & 14 \\
\hline Employer-supported employee volunteering & 13 \\
\hline Parent-friendly company & 10 \\
\hline Employees' health & 8 \\
\hline Support for employees & 7 \\
\hline Integration of employees & 6 \\
\hline Worker participation & 5 \\
\hline Dialogue with employees & 3 \\
\hline $\begin{array}{l}\text { Countering workplace bullying and } \\
\text { harassment }\end{array}$ & 2 \\
\hline Recruitment and adaptation & 1 \\
\hline Work-life balance & 1 \\
\hline
\end{tabular}

Source: self-reported data based on FOB (2014).

Table 4. The areas of labor practices implemented by businesses in Poland in 2015

\begin{tabular}{|l|c|}
\hline Area of labor practice & Frequency of observed labor practices \\
\hline Training and development & 23 \\
\hline Employees' health & 23 \\
\hline Safety in the workplace & 22 \\
\hline Employer-supported employee volunteering & 12 \\
\hline Integration of employees & 8 \\
\hline Worker participation & 6 \\
\hline $\begin{array}{l}\text { Countering workplace bullying and } \\
\text { harassment }\end{array}$ & 6 \\
\hline Parent-friendly company & 4 \\
\hline Support for employees & 4 \\
\hline Recruitment and adaptation & 3 \\
\hline Work-life balance & 2 \\
\hline Dialogue with employees & 0 \\
\hline
\end{tabular}

Source: self-reported data based on FOB (2015).

A detailed analysis of the areas within which labor practices were carried out by businesses in Poland finds that in 2013 the activities that were most frequently implemented were concerned with employer-supported employee volunteering (15 practices), employees' health (13 practices) and training and development (9 practices) (see Table 2). 
In the year 2014 meanwhile the most frequently carried out practices were those involved in safety in the workplace (14 practices), training and development (14 practices) and employer-supported employee volunteering (13 practices) (see Table $3)$.

In 2015 organizations in Poland most frequently performed activities referring to training and development (23 practices), employees' health (23 practices) and workplace safety (22 practices) (see Table 4 ).

The above data show that training and development of employees make up one of the prioritized CSR areas of businesses in Poland. Over the course of the three years analyzed, the greatest dynamics as to the number of labor practices implemented could be observed in the following areas:

- $\quad$ safety in the workplace (from 7 practices in 2013, to 14 practices in 2014 up to 22 practices in 2015),

- training and development (from 9 practices in 2013, 14 practices in 2014, up to 23 practices in 2015),

- employees' health (from 13 practices in 2013, 8 practices in 2014, up to 23 practices in 2015).

The findings elicited through the analysis of the reports Responsible business in Poland. Good practices over the period of 2013-2015 clearly show that the implementation of labor practices represents the key area for social responsibility in Poland. As observed, no less than $25 \%$ of practices contained in the report Responsible business in Poland. Good practices for the year 2015 accounted for labor practices. The highest number of practices included in the report (41\%) refers to social engagement and local community development.

\section{Conclusions}

In accordance with its aim, the paper showed the importance of human capital for contemporary organizations, presented the ISO 26000 guidance on labor practices and defined the impact of those guidelines on business competitiveness, as well as analyzed labor practices implemented by businesses in Poland. Corporate 
social responsibility can be of external dimension (activity addressing first and foremost clients or a local community) and internal (addressing chiefly employees), with the latter providing the focus of this paper. As the analysis findings showed, entrepreneurs in Poland ever more frequently and within an ever greater scope took actions manifesting their responsibility for employees, thus recognizing the key role played by human capital in building competitive advantage of an organization. Maintaining the current trend of incorporating the ISO 26000 guidelines into the management process and carrying out responsible labor practices by businesses in Poland will contribute to workers' improved situation on the labor market and to increased competitiveness of companies in national and global markets. Moreover, employers who treat their employees in a responsible way build the image of a good employer in public awareness. From the point of view of the organization itself, taking responsible actions to the benefit of internal stakeholders, such as employees, fosters increased loyalty and motivation among workers and reduces their turnover and absenteeism.

\section{References}

Bartkowiak G. (2011), Społeczna odpowiedzialność biznesu w aspekcie teoretycznym i empirycznym, Wydawnictwo Difin, Warszawa.

Deloitte (2013), Elastyczność i zmiana horyzontów. Trendy HR 2013, https://www2.deloitte.com/content/dam/Deloitte/pl/Documents/Reports/pl_Raport_trendyHR \%202013_PL_1.pdf [15.12.2018].

Dzieńdziora J., Smolarek M. (2010), Kapitał ludzki w kreowaniu kapitału intelektualnego organizacji, „Zeszyty Naukowe Wyższej Szkoły Humanitas. Zarządzanie”, no 2, pp. 82-95.

Edvinsson L., Malone M.S. (2001), Kapitał intelektualny, Wydawnictwo Naukowe PWN, Warszawa.

Godlewska M. (2008), Kierowanie zasobami ludzkimi, in: Podstawy i metody zarządzania. Wybrane zagadnienia, Weiss E. (ed.), Wydawnictwo Vizja Press \& IT, Warszawa.

Juchnowicz M. (ed.) (2007), Elastyczne zarządzanie kapitałem ludzkim w organizacji wiedzy, Wydawnictwo Difin, Warszawa. 


\section{RESPONSIBILITY FOR EMPLOYEES AS A CHALLENGE FOR ...}

Król H., Ludwiczyński A. (ed.) (2006), Zarządzanie zasobami ludzkimi. Tworzenie kapitału ludzkiego w organizacji, Wydawnictwo Naukowe PWN, Warszawa.

Luo X., Bhattacharya C.B. (2006), Corporate social responsibility, customer satisfaction and market value, ,Journal of Marketing”, vol. 70 no. 4, pp. 1-18.

Forum Odpowiedzialnego Biznesu (FOB) (2013), Odpowiedzialny biznes w Polsce. Dobre praktyki, Forum Odpowiedzialnego Biznesu, Warszawa.

FOB (2014), Odpowiedzialny biznes w Polsce. Dobre praktyki, Forum Odpowiedzialnego Biznesu, Warszawa.

FOB (2015), Odpowiedzialny biznes w Polsce. Dobre praktyki, Forum Odpowiedzialnego Biznesu, Warszawa.

Pocztowski A. (2007), Zarządzanie zasobami ludzkimi. Strategie - procesy - metody, Polskie Wydawnictwo Ekonomiczne, Warszawa.

Polski Komitet Normalizacyjny (PKN) (2010), Odkrywając ISO 26000, https://www.mpit.gov.pl/media/42609/discovering_iso_26000.pdf [15.12.2018].

PKN (2012), PN-ISO 26000, listopad 2012. Wytyczne dotyczące społecznej odpowiedzialności, $\quad$ http://www.face-design.pl/images/PN-ISO-26000-2012P.pdf [15.12.2018].

Rosińska M. (2007), Kapitał ludzki podstawą budowania przewagi konkurencyjnej współczesnych przedsiębiorstw, in: Uwarunkowania budowania konkurencyjności przedsiębiorstw w otoczeniu globalnym, Bogdanienko J., Kuzel M., Sobczak I. (eds.), Wydawnictwo Adam Marszałek, Toruń, pp. 11-20.

Samul J. (2013), Definicje kapitału ludzkiego w ujęciu porównawczym, „Zeszyty Naukowe Uniwersytetu Przyrodniczo-Humanistycznego w Siedlcach”, no. 23, pp. 195-204.

Skrzypek E. (2009), Kreatywność pracowników wiedzy i ich wpływ na innowacyjność przedsiębiorstw, in: Kapitał intelektualny i jego ochrona, Okoń-Horodyńska E., Wisła R. (eds.), Instytut Wiedzy i Innowacji, Warszawa, pp. 203-214. 